Kowalewski Michal. The role of physical activity in the proper development of a child in preschool age. Journal of Education, Health and Sport. 2020;10(12):185-191. eISSN 2391-8306. DOI http://dx.doi.org/10.12775/JEHS.2020.10.12.018

https://apcz.umk.pl/czasopisma/index.php/JEHS/article/view/JEHS.2020.10.12.018

https://zenodo.org/record/4398486

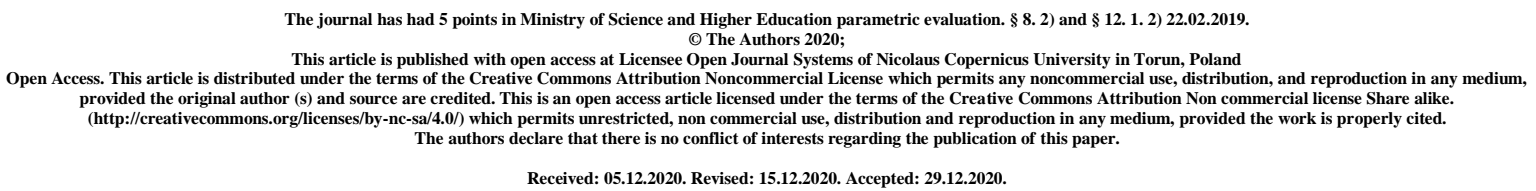

\title{
The role of physical activity in the proper development of a child in preschool age
}

\author{
Michał Kowalewski \\ University of Lodz, Faculty of Educational Sciences, The Department of Pedagogy \\ of Childhood, mail: michal.kowalewski@now.uni.lodz.pl
}

\begin{abstract}
This article aims to pay special attention to the role of physical activity in the proper development of a preschool child, both physically, mentally and socially. It emphasizes the special role of motor games in shaping motor skills, also needed at the next stage of education, at school, as well as the appropriate preparation of teachers to conduct motor activities in preschool education.
\end{abstract}

Key words: physical activity, psychophysical development of preschool children

\section{Introduction}

The concept of physical activity is often used interchangeably with motor activity. Movement or physical activity is defined as a muscular effort that causes a set of changes in the body that lead to energy expenditure higher than the resting level ${ }^{1}$. J. Barankiewicz, in turn, understands physical activity as undertaking various types of exercises and sports disciplines as part of active recreation, for pleasure, recreation and health, improving exercise capacity, gaining special fitness and physical skills, preventing the emergence of civilization diseases, increasing beneficial effects on the fitness for physical and mental work ${ }^{2}$.

\footnotetext{
${ }^{1}$ R. Przewęda. Promocja zdrowia przez wychowanie fizyczne [w:] Promocja zdrowia. J. B. Karski (red.), Warszawa 1999. 201. Polish.

${ }^{2}$ J. Barankiewicz, Leksykon wychowania fizycznego, Warszawa 1998. 11. Polish.
} 
Physical activity and a healthy lifestyle are closely related. The human body requires regular physical activity to function optimally and to avoid disease. Movement not only promotes the functioning and development of the human body, but also has a very beneficial effect on its psyche and well-being. ${ }^{3}$. Regular physical activity can save a person from numerous health problems, but it should be remembered that it is good for health when it is carried out in an appropriate intensity and frequency only ${ }^{4}$. It is a key and integrating component of a healthy lifestyle. Without it, any strategy of health, its maintenance and multiplication is impossible as well as in the case of children, any proper development.

\section{Motor development of a preschool child}

The period most favorable to the development of children's physical activity is the preschool period.

The physical development of a child in this period is characterized by dynamics. This concept is extremely extensive, as it covers all biological, biochemical and biophysical processes that take place in the human body from birth until death. These processes condition the growth and maturation of the body. The changes we observe in humans are the result of these processes. They follow each other in a specific order and direction and are irreversible ${ }^{5}$.

Physical development has not been consistent throughout the four-year pre-school period. The changes taking place each year are more or less varied. The basic indicators of a child's physical development are changes in the body structure and locomotor system ${ }^{6}$. At the age of 3-7 years, a child's body changes on a large scale. Children aged three and four still have the build of a small child: a large head, long torso, short limbs, as well as weak and inefficient feet. Bones are flexible, delicate and the spine has not yet established physiological curves. Muscle fibres are characterized by a large amount of water and laxity. The child's joints are mobile, and their ligaments are stretchy and weak, which significantly affects their low resistance to physical exertion.

In the fifth year of life, there is an increase in body muscularity, especially in the legs and torso, which increases strength. Older children become capable of greater efforts. The whole body becomes more proportional, which makes the silhouette slimmer ${ }^{7}$.

At 3-6 years of age, the child runs, jumps, picks up things from the ground, etc., and this mobility is interwoven with frequent rests. This "hunger for movement" is caused by a child's natural need to exercise their muscles, bones, heart and lungs. Such "natural movement", i.e. play as the main element of a child's psychophysical life, does not exhaust him. With age, the dexterity of movement and better cooperation of the muscles increase, which is associated with a better functioning nervous system ${ }^{8}$.

\footnotetext{
${ }^{3}$ M. Napierała i in., Aktywność fizyczna $w$ zdrowym stylu życia bydgoskich gimnazjalistów, ,Journal of Health Sciences", 2014;4(11):11-32. ISSN 1429-9623 / 2300-665X http://journal.rsw.edu.pl/index.php/JHS/article/view/2014\%3B4\%2810\%29\%3A11-32 DOI: 10.13140/2.1.2877.2803 http://dx.doi.org/10.13140/2.1.2877.2803. 21. Polish.

${ }^{4}$ Ibidem. 15.

${ }^{5}$ R. Kurniewicz-Witczakowa. Rozwój fizyczny. Uwagi wstępne o rozwoju, [w]: Dziecko w wieku przedszkolnym. Rozwój fizyczny. Rozwój psychiczny i wychowanie. Racjonalna opieka domowa nad zdrowiem dziecka. Żywienie. D. Chrzanowska, L. Dzieniszewska-Klepacka (red.). Warszawa 1974. 11. Polish.

${ }^{6}$ A. Klim-Klimaszewska. Pedagogika przedszkolna. Nowa podstawa programowa. Warszawa 2012. 40. Polish.

${ }^{7}$ Ibidem.

${ }^{8}$ J. Bogdanowicz. Rozwój fizyczny dziecka. Warszawa 1957. 65. Polish.
} 
In the preschool period, the child gradually improves his physical fitness. He starts to run faster and farther and jump higher, he learns to ride a bike on his own and to climb ladders on the playground. During this time, in motor skills of five-year-old children, an improvement in coordination skills is observed.

Agility is the motor coordination of the entire muscular and bone apparatus. Power is defined as a complex feature used to determine the relationship between force and speed in motor activities and actions. According to M. Demel, "power understood as a feature of motor skills is defined as the product of force and speed or as the quotient of work by the time it is performed"9. Speed is defined as the ability to make movements in the shortest time. Considered as a feature of motor activity has only one dimension, it is the time. On the other hand, the speed in individual motor activities may be different, it is not easy so to define a general speed, which could be considered an individual feature and on its basis, assess the motor development of the child. Speed is more related to the type of movements performed and therefore it most often relates to specific motor situations ${ }^{10}$.

When analysing motor development, attention should be paid to the important role that motor skills play in various areas of life. It influences social, cognitive, physical as well as sensory and emotional development. This is what human relationships depend on. If the child has a lower level of motor development than his peers, he/ she may be excluded, and situations in which physical activity will be required may become embarrassing for him/ her and will be avoided.

Such a deficit of movement and the reluctance to undertake it often have many negative effects both for the developing organism and for the future functioning of the child in the group. Motor skills are useful in the kindergarten environment, because the child will be more willing to participate in various types of games, and will also be more efficient in manipulating objects and toys. Thanks to such abilities, the child usually becomes more independent and self-confident ${ }^{11}$. Motor skills are also related to the intellectual sphere, therefore poorly developed motor skills cause uncertainty, clumsiness, slowness and a lack of independence.

\section{Strengthening the development of preschool children through games and physical activities}

Physical activity is of great importance in increasing the functional abilities of the body and increasing the mobility of children. Attempts to organize various types of sports competitions and games for children have proved that children are willing to take part in them, showing a lot of activity and independence.

The atmosphere of emotional tension, the willingness to try one's hand at one's disposal creates an extremely wide range of opportunities for educational influence. Running, jumping, throwing the child develops its initiative to freedom of action, the purpose and scope specified in the relevant regulations (respect for them is a reliable way to shaping children conscious discipline, sophistication in their interaction skills, solidarity and camaraderie, developing ambition and a sense of responsibility).

\footnotetext{
${ }^{9}$ M. Demel, A. Skład. Teoria wychowania fizycznego dla pedagogów. Warszawa 1986. 20. Polish.

${ }^{10}$ R. Przewęda. Rozwój somatyczny i motoryczny. Warszawa 1973. 130-131. Polish.

${ }^{11}$ Ibidem. 159.
} 
Subordinating the activity to the laws and needs of the team results from the very essence of the exercises. Measurability of results, the possibility of achieving progress, joy and pride in victory - this is a strong incentive to develop endurance in pursuing the goal. Most sports and entertainment elements can be found in sports games and physical activities. When we give these games: races, jumps and throws, the setting of the competition, when we organize a jury committee, give the children a stopwatch, we will receive a sports event full of emotional experiences, with great values shaping the child's fitness, developing its character, preparing for reliable work.

In addition, arcade games and activities are to ensure an active rest for the child. Movement stimulates other analyzers to work than those needed for mental work and facilitates the regeneration of tired nerve tissues. Movement and skill activities enrich the child's experience and movement habits. Sports and entertainment include all these forms of movement, during which we organize team competition. We do not distinguish units even in individual competitions. The sum of times or distances determines the team's victory. When organizing sports competitions, it is necessary to ensure the safety of children and the appropriate educational atmosphere. They shape the character of the child - the joy of action and satisfaction with achievements gives him self-esteem.

The aim of movement exercises is to develop fitness, speed, strength and dexterity, which will be useful especially at the beginning of the next stage of education - early school education. Enriching the mental life of older children presents the teacher with a difficult problem of satisfying the natural needs of a child with a wide and varied program of sports and play activities. Some children are eager to return to various games they have learned in previous years, most want to imitate youth, watch sports competitions, handball and football games, volleyball, basketball, and want to practice real sports.

Fun and movement games are rich and simple at the same time. Based on utilitarian forms of movement (walking, running, throwing, crawling), they have a comprehensive effect on the human system (organism), contributing to increasing its efficiency and general physical fitness. They surpass other forms of motor activity with their diversity, freedom of action, the possibility of choosing motor solutions that allow the even involvement of all muscle parts, internal organs, and the nervous system, which creates an opportunity for a comprehensive and multidirectional impact on the child (per individual).

The activities of preschool children are based primarily on games and simple movement games. After M. Bondarowicz and T. Staniszewski, these are:

1. Games with singing and music;

2. Orientation and order games;

3. Running games;

4. Jumping games;

5. Throwing games;

6. Kicking games;

7. Clamping and lifting games ${ }^{12}$.

\footnotetext{
${ }^{12}$ M. Bondarowicz, T. Staniszewski. Podstawy teorii i metodyki zabaw i gier ruchowych. AWF. Warszawa 2000. 22. Polish.
} 
Simple games are based on the imitation, task method, direct purposefulness of movement and movement story. The variety of types of games and movement games included in this course is a guarantee that the principle of versatility is respected. This allows you to achieve the correct intensity of physical effort, of course, with the appropriate selection of games and movement games.

\section{The role of teachers in the implementation of health and motor education in preschool children}

Health and motor education of children is aimed at ensuring their harmonious psychophysical development, providing them with the necessary knowledge and skills for health and physical fitness, learning how to cooperate in a team and preparing for independent planning of their own physical activity. ${ }^{13}$

It is worth emphasizing that according to the core curriculum for preschool education, the correct diagnosis of a child's physical and motor development is of great importance for the rational management of the physical education process. Thanks to it, it is possible to forecast a child's developmental abilities, and as a result, it is easier and more accurate to manage the teaching process ${ }^{14}$.

The core curriculum for pre-school education indicates the purpose of pre-school education, preventive and educational tasks that the kindergarten performs, as well as the effects of tasks in the form of goals achieved by children at the end of pre-school education ${ }^{15}$. The guidelines contained in this document apply to all spheres of a child's development. The child takes part in movement games, including rhythmic, musical, imitation games with or without the use of accessories, and performs various forms of movement. In addition, he/ she performs basic exercises to shape the habit of maintaining correct body posture.

Caring for the health and proper development of preschool children, educators should use the time that their pupils spend in kindergarten as efficiently as possible. The best solution is organized physical activity that will allow to release excess energy as well as satisfy the need for exercise. All these activities will give children the conditions and the opportunity to achieve balanced mental, intellectual and physical development.

Teachers should create situations that favor physical activity. It is important that they familiarize the pupils with various ways of spending time actively. The task of educators is also to prepare children to spend time actively by properly preparing the place for exercise. As mentioned, preschool age is a period of increased demand for exercise. Therefore, an important role of the kindergarten is to provide the child with appropriate movement patterns, which will significantly affect the correct shaping of the figure, as well as the overall physical fitness, aesthetics and elegance of movement.

\footnotetext{
${ }^{13}$ A. Jaworska. Edukacja zdrowotno-ruchowa. „Bliżej Przedszkola” 2011. nr 3. 6. Polish.

${ }^{14}$ Ibidem. 5.

${ }^{15}$ Regulation of the Minister of National Education of February 14, 2017 on the core curriculum for pre-school education and the core curriculum for general education for primary schools, including students with moderate or severe intellectual disability, general education for the first-degree industry school, general education for special school preparing for work and general education for post-secondary schools, Journal Of Laws 2017 , item 356.
} 
Educators treat the movement as a priority, assigning it great educational and shaping importance. Therefore, it is extremely important to choose the right methods and forms of work that will help motivate the child to be active ${ }^{16}$.

At this point, a question should be asked: to what extent are teachers of preschool children prepared to perform such work during their studies and during apprenticeships? The teacher's task is to skillfully select the forms of movement and dose them appropriately, so that they serve the child's physical and mental health, shape its character and prepare it for activities in various living conditions. The teacher's work should be based on the knowledge of the anatomy and physiological functions of the child's development.

The role of the teacher should be to skillfully activate children by offering them appropriate topics for classes. Children should understand that the sports achievements is a long way through sports training. At the beginning, this training will be based on games and preparatory games for a given sports discipline and sports forms with simplified, simplified tasks.

\section{Conclusion}

Thanks to exercise and physical exertion, the child learns to overcome difficulties, cope with fatigue, learns about its possibilities and limitations, learns to accept successes and deal with failures. It is also important for them to establish a relationship of cooperation and competition with their peers, thanks to which the social aspect of its functioning develops. Physical activity also allows the child to become resistant to harmful external factors. The planned as well as spontaneous physical activity of the child allows to compensate for the immobility of the body that occurs while studying or watching $\mathrm{TV}^{17}$.

Shaping an active attitude to health from an early age is the most important goal and task of health promotion, and the great variety of movement games, the versatility of their impact and the ease of organizing them place them - as K. Wlaźnik emphasizes - in the first position in working with young children.

\footnotetext{
${ }^{16}$ E. Roszka. Aktywizacja ruchowa dzieci. „Bliżej Przedszkola” 2011. nr 4. 60. Polish.

${ }^{17}$ A. Pasternak. Fit, czyli $w$ dobrej formie kultura fizyczna u przedszkolaka. „Bliżej Przedszkola” 2010. nr 111. 20-21. Polish.
} 


\section{Bibliography}

1. Barankiewicz J., Leksykon wychowania fizycznego, Warszawa 1998.

2. Bogdanowicz J., Rozwój fizyczny dziecka, Warszawa 1957.

3. Bondarowicz M., Staniszewski T., Podstawy teorii i metodyki zabaw i gier ruchowych, AWF, Warszawa 2000.

4. Demel M., Skład A., Teoria wychowania fizycznego dla pedagogów, Warszawa 1986.

5. Jaworska A., Edukacja zdrowotno-ruchowa, „Bliżej Przedszkola” 2011, nr 3.

6. Klim-Klimaszewska A., Pedagogika przedszkolna. Nowa podstawa programowa, Warszawa 2012.

7. Kurniewicz-Witczakowa R., Rozwój fizyczny. Uwagi wstępne o rozwoju, [w]: Dziecko w wieku przedszkolnym. Rozwój fizyczny. Rozwój psychiczny i wychowanie. Racjonalna opieka domowa nad zdrowiem dziecka. Żywienie, D. Chrzanowska, L. DzieniszewskaKlepacka (red.), Warszawa 1974.

8. Napierała M., Szark-Eckardt M., Żukowska H., Kuska M., Zukow W., Aktywność fizyczna w zdrowym stylu życia bydgoskich gimnazjalistów, „Journal of Health Sciences”, 2014;4(11):11-32. ISSN 1429-9623 / 2300-665X. http://journal.rsw.edu.pl/index.php/JHS/article/view/2014\%3B4\%2810\%29\%3A11-32

DOI: $\quad 10.13140 / 2.1 .2877 .2803 \quad$ http://dx.doi.org/10.13140/2.1.2877.2803 https://pbn.nauka.gov.pl/works/484149.

9. Nowak M., Muszkieta R., Cieślicka M., Poziom zdolności motorycznych u dzieci w wieku przedszkolnym a uczestnictwo w zajęciach z pływania, Bydgoszcz 2013.

10. Pasternak A., Fit, czyli $w$ dobrej formie kultura fizyczna u przedszkolaka, „Bliżej Przedszkola" 2010, nr 111.

11. Przewęda R., Promocja zdrowia przez wychowanie fizyczne [w:] Promocja zdrowia, J. B. Karski (red.), Warszawa 1999.

12. Przewęda R., Rozwój somatyczny i motoryczny, Warszawa 1973.

13. Roszka E., Aktywizacja ruchowa dzieci, „Bliżej Przedszkola” 2011, nr 4.

14. Regulation of the Minister of National Education of February 14, 2017 on the core curriculum for pre-school education and the core curriculum for general education for primary schools, including students with moderate or severe intellectual disability, general education for the first-degree industry school, general education for special school preparing for work and general education for post-secondary schools, Journal Of Laws 2017, item 356.

15. Wlaźnik K., Wychowanie fizyczne w przedszkolu, PZWSz, Warszawa 1972. 